\title{
Kant on Race and Barbarism: Towards a More Complex View on Racism and Anti-Colonialism in Kant
}

\author{
OLIVER EBERL \\ Leibniz Universität Hannover \\ Email: o.eberl@ipw.uni-hannover.de
}

\begin{abstract}
Whether Kant's late legal theory and his theory of race are contradictory in their account of colonialism has been a much-debated question that is also of highest importance for the evaluation of the Enlightenment's contribution to Europe's colonial expansion and the dispossession and enslavement of native and black peoples. This article discusses the problem by introducing the discourse on barbarism. This neglected discourse is the original and traditional European colonial vocabulary and served the justification of colonialism from ancient Greece throughout the Renaissance to the eighteenth century. Kant's explicit rejection of this discourse and its prejudices reveals his early critical stance toward colonial judgements of native peoples even before he developed his legal theory. This development of his critical position can be traced in his writings on race: although he makes racist statements in these texts, his theory of race is not meant to ground moral judgements on 'races' or a racial hierarchy but to defend the unity of mankind under the given empirical reality of colonial hierarchies.
\end{abstract}

Keywords: theory of race, racism, colonialism, barbarism, legal theory, physical geography, natural history, native peoples, anthropophagy, climate theory, travel writings, Georg Forster

\section{Introduction}

Critics as well as advocates of Kant today agree that his concept of race is committed to the existence of a 'racial hierarchy' and hence itself racist. ${ }^{\mathrm{I}}$ In defence of Kant, Pauline Kleingeld has made a powerful case for 
limiting this diagnosis to Kant's early work and his writings on race during his middle period. Under the assumption that Kant 'radically changed his view on colonialism' (Kleingeld 20I4: 45), Kleingeld contrasts his early colonial racism with Kant's later, non-racist anti-colonialism. ${ }^{2}$ In her reading of Kant's 'second thoughts on race' (Kleingeld 2007), the concept of race became increasingly 'less prominent' in Kant's writing until it ultimately 'no longer fitted' the anti-colonial theory of right he developed in Perpetual Peace (1795) and The Metaphysics of Morals (I797) (Kleingeld 2014: 589, 592). ${ }^{3}$

Robert Bernasconi (20II: 300) has countered that Kant had 'third thoughts on race' when he published further editions of his articles on race after I790 (I793, I797, I799) and made reference in his Anthropology ( $\mathrm{I} 798$ ) to Christoph Girtanner's Concerning the Kantian Principle in Natural History (I 796), which followed Kant's ideas on race. Unless one wants to assume that Kant advocated two mutually exclusive positions at the same time, this suggests the possibility of consistency between Kant's concept of race and his anti-colonialism, as well as the need to reconsider the seemingly fixed interpretation of the former as a racial hierarchy.

To understand colonialism as a consequence of the hierarchical thinking of the Enlightenment is to lose the point of enlightened anti-colonialism. Howard Williams (2014: I79) argues that it is precisely the anti-colonial position that is obscured in today's readings of Kant: informed by the discussion of race, it ends up in the paradoxical position of proving the irrelevance of Kant's arguments against colonialism despite its own anti-colonial interests. When today's readers find patterns of racist thought in historical texts, it shows, at the first instance, only how we think about racism today, because that determines what we seek and find in historical texts. The views and partial theories of Kant, especially his theory of 'races', need to be reconstructed in their historical context. The context of Kant's texts on race is marked by the colonial discourse on barbarism and biosocial climate theory. Given the lack of explanation for a radical and sudden change of opinion in Kant's old age, it makes sense to start from the assumption of consistency between Kant's positions. ${ }^{4}$ It is then possible to trace a sceptical position that Kant began developing much earlier in the view he takes on the colonial 'barbarism discourse'.

Kant's engagement with the colonial discourse on barbarism has been almost entirely overlooked in the debate so far. The concept of the 'barbarian' precedes the one of race and served as a carrier of European 
colonialism for millennia. ${ }^{5}$ It had shaped Europe's idea of the 'Other' since antiquity. Especially Aristotle's description of 'natural slaves' in Book I of his Politics prepared their colonialization and enslavement. Considering the concept of barbarism allows for an approach that avoids the methodological problem, common in the discussion of race, of conflating the two discourses as well as the two concomitant types of degradation. While 'race' is said to establish a hierarchy between different 'races', 'barbarism' establishes a dichotomy: what is in question for a 'barbarian' is not his or her position in an assumed hierarchy but whether he or she can count as a human at all.

This article proceeds in four steps. First, I discuss methodological reasons for taking Kant's dealing with the notion 'barbarism' into account. Then I present Kant's use of the term 'barbarian'. The decisive characteristic here is his reversal of the direction of critique: it is no longer the Other who is degraded as 'barbaric' but rather the European states that are described as 'barbarian' warmongers. In section 4 , I analyse three stages of Kant's concept of race and show that he developed a non-hierarchical concept of race in his middle period $\left(\mathrm{I}_{785}\right)$. The process of self-enlightenment that Kant undergoes in his work on the discourse on barbarism finds its analogue in his concept of race and is most obvious after he started to think about a cosmopolitan legal order in $\mathrm{I} 784$. This background is necessary to elucidate the explanatory function of Kant's thought on 'race'. Finally, I show through an analysis of Kant's debate with Georg Forster that his defence of the monogenetic approach also defends the unity of the human species in an attack on colonialism.

\section{Barbarism, Anti-Colonialism and Kant's Racism}

A common view today identifies not the hierarchy of races, but a dichotomous form of distinction as the main feature of racism: 'The category of race is only one reference point of racism, which has appeared in different historical shapes and has drawn upon several dichotomies, constructing monsters, barbarians, inferiors, the impure, the cursed, savages and eventually coloureds' (Hund 20II: 70). The issue, then, would be cultural degradation and general stereotypes. This view, however, risks losing sight of the differences between the two discourses on race and barbarism. Even though Kant established the concept of race as a philosophical concept (cf. Bernasconi 200I: I I-36), it should nonetheless be distinguished carefully from the discourse on barbarism. ${ }^{6}$ Otherwise, the characteristic feature of the barbarism discourse, that is, the dichotomy of two poles, the 'barbarian' and the 'civilized man', is mistakenly taken to describe the discourse on race, despite the fact the latter functions on 
an entirely different basis in order to create a hierarchical - and not dichotomous - order of races. ${ }^{7}$ I aim to show that Kant's rejection of the barbarism discourse served to criticize colonial prejudices and enabled him to develop his concept of race in this context. Only in distinguishing between the two discourses does a contextualized look at Kant's concept of race become possible and reveal its specific content. It will then also become clear that his concept of race and his anticolonialism can be understood as perfectly consistent. Inés Valdez also argues for consistency, rather than proclaiming a sudden change of heart. She attempts to find consistency in 'Kant's anti-colonialism and his hierarchical understanding of the world', expressed by his race theory (Valdez 20I7: 828). Valdez shows convincingly that Kant connected the colonial wars and cruelties to Europe's future and faith. Therefore, she describes Kant's anti-colonialism as 'Eurocentric' and 'partly motivated by a concern' about the effects of colonialism on European peace and republicanism (820). She also convincingly describes Kant's account of the differences of races as a 'relative weakness' and argues that Kant aimed to protect non-Europeans by cosmopolitan law (832). Only her conclusion, that 'These protections do not imply a retreat from racial and civilizational hierarchies' (832), appears in the light of the barbarism discourse less convincing because, as I will show, Kant attempts to defend the unity of humanity in the writings on race and not the hierarchy of races. So even if Kant's anti-colonialism may be partly Eurocentric, his concern for wrong judgements about non-European peoples comes to the fore in his rejection of the discourse on barbarism, the classical European colonial discourse.

Consequently, we need to change perspective. Rather than look for the confirmation of racism in the concept of race, we should investigate it for signs of anti-colonialism. If the concept of race showed no signs of anti-colonialism, we would have to posit a continuity of degradation of other peoples, and understand the anti-colonialism in Kant's legal theory as an exception and a pure Eurocentric view. Conversely, if we take Kant's anti-colonialism seriously and understand his concept of race in opposition to the concept of the barbarian, aspects of his race theory appear as an analogue to the anti-colonial aspects of his legal theory.

Once such a consistency between Kant's concept of race and his later anticolonial writings has been established, it allows us to return to an investigation of the causes for Kant's change of mind that Pauline Kleingeld has argued for. These causes are anchored in the different perspectives offered by legal theory and the concept of race on the same two 
phenomena, that is, the differing characteristics among the human species and colonial hierarchies as they actually existed. The concept of race is deeply connected to Kant's critical philosophy and part of his attempts to deal with natural history. The theory of race is, as Stella Sandford states, 'the context in which the general problem of a natural system of nature and of the systematic unity of nature, beyond the aggregate of empirical knowledge, is first und fully addressed by Kant' (Sandford 201 8: 964). It follows from this that the description of the phenomenon of colonialism from within a concept of race is not necessarily inconsistent with the condemnation of colonialism in Kant's legal theory. When the concepts of race and right are seen as different perspectives on the development of the human species and its current condition, Kant's concept of race and his anti-colonialism can be seen as complementary parts of a complex explanation rather than as a puzzling inconsistency (Kleingeld 2007: 586).

It is precisely in this sense that Kleingeld's thesis can be confirmed in modified form. In brief, Kant gradually progressed from a popular, Hume-inspired sentiment of superiority (I764) to climate-theoretical race theory ( $\mathrm{I} 775)$ and a value-neutral concept of race ( $\mathrm{I} 785)$, to a teleological concept of race ( $\mathrm{I} 788)$ that allowed him to then condemn colonialism (I795, I797) while adhering to his concept of race (I798). He was able to do so because his writings on race are not intended to justify Europe's colonial expansion but to explain its success and foundations in the perspective of the natural development of the human species.

It is systemically impossible to condemn colonialism within a framework of race because here humans and their development are understood as part of the animal kingdom. It is possible, however, to describe the existing colonial hierarchy of races on this basis. Condemnation, on the other hand, becomes possible only with a concept of right that can determine the legitimacy of relations of power and suppression. ${ }^{8}$ If Kant's racial theory lacks a condemnation of colonialism, this lack does not necessarily signal acceptance or confirmation of colonialism. On the contrary, the coincidence of his first article regarding the idea of a cosmopolitan view on history in $\mathrm{I} 784$ and his most value-neutral assessment of the question of human races in 1785 can be understood as the combination of two perspectives on the problem of war and colonialism: that of the evolution of law and that of the biological history of humankind. Kant does indeed identify racial characteristics as reasons for varying degrees of technological and social differentiation, leading to European dominance, but he explains them as the results of unavoidable, 
prehistorical adaptation to climatic conditions. In the case of extremely hot climates, Kant posits the inevitable adoption of 'indolence' (Trägheit), and 'indolent' societies are therefore unable to develop 'European' vitality and remain in a nomadic or pre-state stage, rendering them largely defenceless objects of European colonialism.

\section{Kant's Transformation of the Colonial Concept of 'Barbarian' into a Concept for Criticism of European States}

Kant reverses the colonial discourse on barbarism into a concept that can serve to criticize European states on the basis of his critical reception of the reports on other peoples that had been collected in the process of European expansion. This critical turn is an important feature of the European anti-colonial tradition from Las Casas and Montaigne to Rousseau and French enlightenment thinkers like Diderot (Fink-Eitel I984, Eberl 2018). Kant clearly proves his commitment to these predecessors by dealing with colonial judgements. Kant's engagement with popular travel reports provides the key to explaining the change from an obviously uncritical feeling of superiority in 1764 to a value-neutral concept of race in 1785 . Where Kant first uncritically trusted and accepted the description of and judgements on foreign peoples in those travel reports ( $\mathrm{I} 764)$, he ultimately became so critical of them $(\mathrm{I} 785)$ that Georg Forster as a representative of the (new) travel writers understood Kant's critique as a personal attack and initiated a debate.

While it is true that, in Emmanuel Chukwudi Eze's words, Kant's 'reliance on explorers, missionaries, seekers after wealth and fame, colonizers. etc. and their travelogues provided or served to validate Kant's worst characterization of non-Europeans "races" and cultures', it is nonetheless mistaken to claim that 'Kant believed that travel stories provided accurate or factual information for academic science' (Eze I997: I 29, I27-8). Similarly, Thomas McCarthy holds that Kant 'warned repeatedly of the unreliability of such sources, but rely on them he did. As a result ... he largely repeated the racist commonplaces of the period. And in his account these commonplaces were naturalized through being biologized' (McCarthy 2009: 49). While McCarthy identifies old prejudices as the theoretical foundation of Kant's concept of race, Eze seeks to prove that Kant provided a new justification of racial superiority. Kant's doubts and warnings concerning the travel reports disappear from view in both Eze and McCarthy because both writers remain focused on the issue of 'racial differentiation'. In contrast, an investigation within the framework of the barbarism discourse shows that Kant criticizes old prejudices. 
A crucial source of Kant's engagement with the barbarism discourse is his detailed description of colonial possessions and conditions in his lectures on Physical Geography. Kant presented these lectures annually, from I757 until the end of his teaching career in I796. The published version was by no means written by Kant (cf. Stark 20II) and contains statements from all periods of the development of this theory: climate theory, the skin and its colour, as well as elements that became less important over time and on which Kant changed his position. As an example, consider the passage on the development of skin colour. On one and the same page, it claims that skin colour results from exposure to heat, and that it results from nutrition, exposure to air and from education ( $P G, 9: 3 \mathrm{I} 4) .{ }^{9}$ These claims directly contradict one another, and Kant ultimately maintained only the former. The drastic formulations in his lectures are often read as a confirmation of Kant's racism, ${ }^{10}$ but are indeed only conventional judgements from travel reports from a time when Kant accepted their claims largely uncritically. They correspond roughly to those prejudices in Kant's early Observations on the Feeling of the Beautiful and Sublime (I764). Importantly, they are not only uncritical but also were articulated before Kant developed his concept of race.

Eventually, Kant published his essay on the 'races of human beings' in $\mathrm{I} 775$, including a description of a hierarchy of races. His choice of words there comes very close to a particular passage in the Physical Geography:

In the torrid zones, humans mature more quickly in all aspects than in the temperate zones, but they fail to reach the same [degree of] perfection. Humanity has its highest degree of perfection in the white race. The yellow Indians have a somewhat lesser talent. The Negroes are much lower, and lowest of all is part of the American races. $(P G, 9: 316)$

Werner Stark has shown that Kant's original first manuscript dates from the years I 757 to I759, and that this passage originated around I 775 and was further embellished by Kant's publisher Rink and the students taking notes (Stark 20II). It is possible, then, that 'perfection' (Vollkommenheit) here refers to the adaptation to natural conditions in the sense of the climate-theoretical assumptions of Kant's essay on human races from I 775. This position grows gradually less important in both Kant's lectures and his writings on race theory.

In his announcement of the lecture in $\mathrm{I} 757$, Kant writes that he plans to proceed 'with the reasoned curiosity of a traveller who everywhere looks 
for the noteworthy, the strange, and the beautiful, compares the observations he has collected, and revises his ideas accordingly' (APG, 2: 3). He provides a detailed list of travel reports that represent the scientific knowledge of the time. ${ }^{\mathrm{II}}$ It is this idea of capturing the natural world with a method that focuses on the 'noteworthy' (merkwürdige) and incorporates it into a 'system' that Kant increasingly comes to doubt over time. At the same time, Linné incorporated pejorative descriptions on different human species in his Systema Naturae in 1758, which matches the preparations for Kant's first lecture. ${ }^{\mathrm{I2}}$

Kant's rejection of this pejorative reasoning and the credibility of the travel reports is particularly obvious in his treatment of cannibalism. Anthropophagy was an essential topos of the barbarism discourse and played an important part in describing the native population of South America. Along with human sacrifice, anthropophagy functioned as proof of godlessness and as a foundation for legitimizing a 'just war' against 'barbarians' (Pagden I990). Of the inhabitants of the islands of Nicobar and Andaman, Kant writes: 'They are falsely accused of being cannibals. In general, the most reliable travellers, Dampier among them, have found this cruel custom, which has been ascribed to many unknown peoples, to be untrue' ( $P G, 9: 393)$. Perhaps Kant's note that the inhabitants are also 'tall and well-proportioned' helps explain why he rushed to defend their reputation. More importantly, the passage refers to the sensationalized reports of irrational travellers, of whom there appear to be many. Kant bluntly rejects the genre of horror stories, which usually allege cannibalism, and it is likely that in the course of this revision he also came to reject the other extreme, the image of the 'noble savage', which he had still adopted in his Observations. It is clear to Kant that 'the giants in Patagonia are figments of the imagination. ... The people described by Pliny, with one eye, hunch backs, one foot, without a mouth, races of dwarfs, and so on, also belong in this category' ( $P G, 9: 315)$.

And yet, there are other passages. Concerning some peoples, Kant apparently accepts the reports of cannibalism. On the Anzikos, Kant notes that 'according to missionary reports, human flesh from fat slaves, properly butchered for the purpose, is on sale on their markets' ( $P G, 9: 4 \mathrm{I} 2)$. In South America, the Tapeje are reported to 'devour captured enemies'. A passage further down shows that this is not a thoroughly composed and consistent manuscript: 'A prisoner taken in battle is cared for very well at first, is even given a woman to sleep with, but afterwards he is killed and eaten, without, however, being tortured. All strangers are well received. The humming bird is said to sing very beautifully here, which it 
does not do in North America' (430). The way these three pieces of information are bundled together suggests either that Kant did not present them in this way or, even if he did, that they are older passages put together almost arbitrarily.

The same holds for a statement on Paraguay that reads as if taken straight out of the classic barbarism discourse: 'The savages of this country are dangerous cannibals' $(P G, 9: 43 \mathrm{I})$. The same paragraph mentions a I 746 study of the coast south of Buenos Aires, suggesting that the passage dates from the early iterations of Kant's lecture in the I750 s or I760 s. Another passage alleging that 'Eskimos' ate their wives and children when running short of food during their travels refers to a report by Captain Ellis dating from 1746 (432). The Indians of North America, on the other hand, are said to either adopt prisoners of war into their own families in time, or torture, cook and eat them. Kant also provides an explanation for this behaviour: 'This occurs more from the desire to appease the spirit of the man killed by means of a vengeance sacrifice than from appetite' (433).

Kant's choice of words suggests a gradual development of his judgement, moving from the uncritical citing of reports as facts ('are') to careful distancing ('it is reported', wird berichtet), attempts at explanation ('appease') and, finally, strong and general scepticism and disbelief ('falsely accused [of] this cruel custom', angedichtete Grausamkeit). The development of Kant's judgement could only have occurred in this direction of self-enlightenment: the reference to travellers who doubted the veracity of tales of cannibalism must have been added later than the cited travel reports because the opposite case - general rejection of those tales first, uncritical reference later - would be self-contradictory and require further explanation to the lecture's audience. It can therefore be assumed that the passages typical of the barbarism discourse came first. Later, Kant develops an ironic use of cannibalism when he compares the European way of treating defeated enemies with that of the cannibalistic 'savages' and comes to the result that the Europeans would 'know how to make better use' of them for 'even more extensive wars' (PP, 8: 354).

Kant did not stop at criticizing those untrustworthy reports. He systematically transformed a classical concept used for degrading other peoples and cultures into a concept used to criticize European states. The moral judgements that were part of the barbarism discourse - bellicose brutishness, intellectual limitation - are well known to Kant, who speaks in 
Perpetual Peace of the 'barbarous, crude, and brutishly degrading to humanity, the attachment of savages to their lawless freedom' $(P P, 8: 354)$. That Kant was very well aware of the conventional use of the designation 'barbaric' for colonialized peoples and the misuse of the concept of hospitality can be seen in this passage: 'The principle of the supposed justice of acquiring newly discovered lands, taken for barbaric or unbelieving, as ownerless goods without the authorization of the inhabitants and even by subjugating them, are every one absolutely contrary to cosmopolitan rights limited to mere hospitality' (DR, 23: I74). He turned them against the Europeans by using the term 'barbaric' to describe the warring behaviour of European states in his legal philosophy. In his 'Idea for a Universal History with a Cosmopolitan Intent' (I784), Kant writes:

This the barbaric freedom of already established states also does, namely, that through the application of all powers of the commonwealth to armaments against one another, through the devastations perpetrated by war, even more, however, through the necessity of preserving themselves constantly in readiness for it, the full development of the natural predispositions are restrained in their progress. (IUH, 8: 26)

In the Critique of Judgement (I790), Kant refers to the 'barbarism of wars' (CJ, 5: 430); in Perpetual Peace (I 795), he condemns the 'barbaric means of war' (PP, 8: 357); and in the Metaphysics of Morals ( 1797$)$, he demands that nations '[decide] their disputes in a civil way, as if by a lawsuit, rather than in a barbaric way (the way of savages), namely by war' (MM, 6: 35 I). In his reflections on anthropology, finally, Kant notes that 'there is still something barbaric about states, in that they are unwilling to submit to the force of law in regards to their neighbours' and 'in terms of international law, we still are barbarians' (RA, I 5: 6I7, 634; translation mine). Even the legislation of criminal law can be 'barbarous and undeveloped' (MM, 6: 337). ${ }^{\mathrm{I}}$

Taken together, Kant's arguments proceed on two levels: on the one hand, he incorporates the European discovery of a variety of foreign peoples into his Physical Geography, with the intent of accurately representing the contemporary knowledge of the world that includes colonialism; on the other, he develops an agenda against the consequences of these discoveries in his later writings on legal theory, where he condemns colonialism, sketches a system of juridification that would constrain colonialism, and turns the pejorative concept of barbarism against the European states. 
Kant's search for the foundational causes for the success of European expansion and the underlying superiority of European economies, technology, weapons, as well as state and social institutions and personality traits such as discipline and will power, leads him to race theory. The essential function of race theory is to explain unity in a world of differences - not, as is often assumed - the differences in a unified world. 'Race' is the 'view of a mere describer of nature whose interest is unity' (Sandford 2018: 965) and 'not an empirical category for determining judgement' (20). The world creates differences itself and it does not take a philosopher to point them out; the world needs a philosopher to at least allege unity against the reality of difference. ${ }^{\mathrm{I}} \mathrm{Kant}$ 's description of racial characteristics, therefore, has as its starting point those differences that made history possible as it occurred: expansionary Europeans meet unprepared peoples and nations (with the exceptions of China and Japan). The causes for the advantages and disadvantages of both European and non-European peoples at the time of interaction are explained through race theory, but this theory is not the place for either condemnation or overcoming of actual, given conditions. Those can be found only in the later Kant's legal theory.

\section{The Development of Kant's Concept of Race}

The prejudices of the travel reports are the prejudices of the barbarism discourse. Since Kant developed a critical stance towards them, it is reasonable to investigate whether his race theory really converts the prejudices of the barbarism discourse into a biological-natural history, based on units he identifies as 'races' in order to explain and justify colonialism.

This endeavour requires consideration of the specific meaning of the concept of race. If, as Bernasconi puts it, 'racism is always shifting its character' (2OII: 30I), then anti-racism and anti-colonialism also need to shift their characters. It follows that we have to pay much more serious attention to the fact that it was Kant's primary goal to refute the theory of polygenism, that is, the assumption that human beings descend from different tribes or races (293). One could think of race as an idea that allowed philosophers to combine considerations of common origin and hereditary difference (Hund I999: I23). It is just that point of common origin that has so far been direly neglected vis-à-vis the issue of difference. I am going to discuss this aspect by way of analysing Kant's writings on race, in order to show that his attempt to determine the characteristics of given 'races' as a combination of unity and difference mirrors his critique of the barbarism discourse and can explain the causes of the differences between societies and thus the success of colonialism. 
The gradual change of heart visible in Kant's lectures on physical geography can also be found in his writings on race. His contributions there had to engage with the discussion of the Gestalt of the human species. Aside from the biological theories of Karl von Linné (I735) and Johann Blumenbach (I775), the main source for the debate over unity and difference in the human species was a climate theory that dated back to antiquity and was popularized by Montesquieu's The Spirit of the Laws (I748). This theory made it possible to at least attempt an explanation of the obvious differences in skin colour or hair texture as adaptations to the environment, leaving open the question of how long those adaptations (such as skin colour) would last. Since its early days in ancient ethnography, climate theory had also been connected to the theory of 'extremes': it identified in the North the deprived life of hunters in extreme cold, in the heat of the South a life of laziness and comfort, and only in the middle the possibility for a balance of climate and character. This theory explains the particular interest in the eighteenth century for both the then-called 'Eskimos' and 'Lapps' in the furthest North and the 'Hottentots' in the south of Africa. Only the middle region of temperate climate seemed to allow the development of higher civilizations, and this self-certitude typifies European Eurocentrism in the mid-eighteenth century.

Monogenists like Buffon were confronted with the problem of explaining how the original human population could have developed into groups of different skin colour. A competing answer was given by polygenism, the thesis of human origins in different tribes (Sandford 2018: 962ff., Jablonski 2OI2: I27). Kant's chain of argument clearly suggests a development from the uncritical acceptance of general stereotypes and prejudices toward a more critical position.

In I764, Kant published his Observations on the Feeling of the Beautiful and Sublime, a text full of facile observations on how different character types, men and women, different European nations, and finally nonEuropean peoples, relate to questions of beauty. The descriptions of Canadian Indians and Africans stand out in this essay. For the African population, Kant shows only disdain: 'The Negroes of Africa have by nature no feeling that rises above the ridiculous', and their feeling of beauty hence remains unconnected to what is noble $(O B S, 2: 253)$. To support his thesis, Kant refers to the claim David Hume made in his essay on 'National Character' (I748) (Hume n.d.: I23), that no 'black man' had ever made significant contributions to the arts or sciences, even when he had acquired freedom in Europe $(O B S, 2: 253)$. Kant should have 
known this claim to be false, even by his own definitions: the example of Anton Wilhelm Amo, who had come from Africa, had studied at the universities of Halle, Wittenberg and Jena, and had ultimately become an Enlightenment thinker in his own right and been recognized as such by Johann Friedrich Blumenbach and others (cf. Ette 20I4: 86), was enough to debunk Hume's theory there and then. Kant simply ignored it, and his uncompromising judgements on Africa's black population ${ }^{\mathrm{I} 5}$ stands in contrast to his empathetic judgement on the Canadian Indians, whom he may have been familiar with from de Lahontan's reports (see Lahontan 1973, 1982): 'Among all the savages there is no people which demonstrates such a sublime character of mind as that of North America' (OBS, 2: 253). His description of native Canadians is reminiscent of Rousseau's picture of the 'noble savage'. ${ }^{16}$ Kant sharply distinguished between these noble Canadian Indians and all others. Keeping with the tradition, he presents a dichotomy of 'good' and 'evil' savages without being able to explain the difference or developing any serious interest in it. This uncritical approach can be seen in the judgements he simply accepts, and which ultimately take him to the picture of the 'noble savage' he will later strongly refute in his writings on the philosophy of history.

In an early version of an infamous footnote, Hume had suspected 'the negroes, and in general all the other species of men (for there are four or five different kinds) to be naturally inferior to the whites' (see Garrett 2000: I7I). Hume, however, had developed this view explicitly in opposition to Montesquieu's climate theory, due to the theory's problems in accounting for similarities and differences within and across different sets of climatic conditions. In contrast, Hume favours 'moral causes', understood primarily as political institutions or forms of government, over 'physical' ones such as 'air and climate' in explaining differences (Hume n.d.: I 20).

Kant rejects this line of reasoning and defends climate theory on a higher level than that of political institutions, namely that of what he calls 'races'. He, too, postulates that there are four races, designated by skin colour. The impact of climate on the development of 'races' which all descend from a common origin is the subject of the race theory that Kant eventually develops. His 'Plan and Announcement of a Series of Lectures on Physical Geography' (I757) does not yet mention races (APG, 2: I-I 2). This suggests that he felt inspired to introduce the term by Hume (and by the French discourse, Voltaire among others ${ }^{17}$ ), even though he rejects both Hume's (and Voltaire's) polygenetic approach 
and his method of observing 'political' institutions as a way of proving the difference between 'races' (which, on a side note, remains within the tradition of the barbarism discourse) in favour of one that 'merely considers the natural characteristics of the globe and what is on it' (3).

In I775, Kant published his essay 'Of the Different Races of Human Beings', referring directly to climate theory and accepting its idea of the development of extremes or polar opposites. From the beginning, Kant refers to Buffon's rule according to which all animals which produce fertile young with one another belong to one and the same species (ODR, 2: 429). From this, he concludes the common origin of all 'races'. In other words, Kant begins his first attempt at defining a concept of humankind by searching for the cause of its common origin, not the differences within it. The 'hereditary differences of the animals ... which persistently preserve themselves ... over prolonged generations' determine their 'race', and Kant hence uses the terms also for humans who are seen here as part of the animal kingdom. After this brief introduction, Kant turns to the much-discussed issue of classifying the 'black' peoples and stresses his monogenetic conviction: 'In this way, Negroes and whites, while not different kinds of human beings (since they belong presumably to one phylum), are still two different races because each of the two perpetuates itself in all regions' (430). Blondes and brunettes are 'strains' (Spielarten) within the 'white race', whereas hereditary differences within one 'race' are termed 'varieties' (Varietäten). This distinction is followed by a division of humankind into four 'races': 'the race of the whites', 'the Negro race', 'the Hunnish (Mongolian or Kalmuckian) race' and 'the Hindu or Hindustani race' (432).

Kant identifies 'natural predispositions', or 'germs' (Keime) as the cause for the development of these 'races' (ODR, 2: 434). In line with the assumptions of climate theory, he argues that air and sun, but not nutrition, 'produce an enduring development of the germs and dispositions, i.e., are able to establish a race' (436). In the 'glacial zone', for instance, human beings develop small stature, reduced hair growth, protection of the eyes and the red-brown skin-colour of the 'Kalmuckian race' (ibid.). After an interlude of casual remarks on the character of native Americans and their 'half extinguished life power' which qualifies them only for slave labour in the house while African slaves are needed for labour in the fields (438), Kant continues his elaboration of the climate theory problem of opposites. Notably, there is no longer any trace of his positive evaluations of native Canadians in his Observations on the Feeling of the Beautiful and Sublime. 
In 'the greatest humid heat of the warm climate', '[t]he exact opposite of the Kalmuckian formation will be produced'. Nose and lips have to become 'thick', and skin has to become 'oiled' to protect against evaporation and 'putrefactive humid elements of the air'. The evaporation of 'phosphorous acid' is theorized to create a distinctive 'stink' and black skin colour. In extreme heat, humans develop characteristics understood as adaptation: 'this results in the Negro, who is well suited to his climate, namely strong, fleshy, supple, but who, given the abundant provision of his mother land, is lazy, soft and trifling' (ODR, 2: 438). Kant contrasts his theory of race as germs adapting to climate and then developing into four phenotypes with 'other conjectures which find the differences in the human species so incompatible that they rather assume on that account many local creations' (440). He names Voltaire as a representative of the latter school.

Kant now turns to the question of the original species (Stammgattung), which either must have died out or must approximate one of the currently existing races. His answer refers back to classic climate theory and its assumption of the superiority of the mean - which can be found only in the 'ancient world', whose white inhabitants must have been closest to the 'original formation' (ODR, 2: 440-I).

Kant is well aware that this does not yet answer the crucial climate theory question of why 'similar countries and regions still do not contain the same race' (ODR, 2: 44I). He asks why America, also characterized by heat and humidity, is not inhabited by a 'black' race, and concludes that germs can no longer be altered once developed into a race (442). Kant has to come to this conclusion or be willing to give up on Buffon's general rule. His negative evaluation of races follows the logic of climate theory: geographically extreme regions give rise to the development of polar types of humanity, in the South as well as in the North. 'Black' populations are 'lazy' because of climate and abundance, suggesting a type of adaptation inevitable for biological beings. There is no explanation for the 'half extinguished life power' found in Americans, but Kant cautiously suggests a connection to their quick expansion into the South. Similarly, there is no explanation for Kant's negative evaluations of Africans. These evaluations stem from climate theory and common prejudices of the time. The different races' lines of descent are not an elaborate hierarchy: the process of descent belongs to the field of natural history, whereas any hierarchy would be found in the field of observation. ${ }^{\mathrm{I}}$ 
Following his climate-theoretic treatment of race in $\mathbf{1} 775$, Kant publishes another essay on race, 'Determination of the Concept of a Human Race', in $\mathrm{I}_{7} 8$. He now begins his discussion from a position of explicit scepticism concerning the existing knowledge of foreign peoples. From the very beginning, Kant asserts that the knowledge of the 'manifoldnesses in the human species' produced by the 'new travels' has 'contributed more to exciting the understanding to investigation on this point than to satisfying it. It is of great consequence to have previously determined the concept one wants to elucidate through observation before questioning experience about it' (DCR, 8: 9I). This methodological innovation is a response to the dubious state of contemporary knowledge. The intent remains to prove the unity of the human species. Kant wants to restrict his discussion to the most fundamental issues and argues that the only hereditary difference among the human species is skin colour. In his schema, there are four types: 'whites', 'yellow Indians', 'Negroes' and 'copper-red Americans' (93).

There is no mention of 'laziness' or 'slackness' in this essay, nor a racial hierarchy of descent or other evaluations. Kant reiterates his assumption of the inevitable heredity of skin colour and insists that 'those four differences in color are the only ones among all hereditary characters that are unfailingly hereditary' (DCR, 8: 98). They are ingrained in the 'germs' of the 'original phylum' and ensure the suitability of human beings to different regions. Once again Kant rejects the assumption of different species of human beings and stresses the feature of commonality that is contained in his concept of race: 'Thus the concept of a race contains first the concept of a common phylum, second necessarily hereditary characters of the classificatory difference among the latter's descendants' (99).

This differentiation allows Kant to retain the unity of the human species. It suggests that the difference is 'only' on the level of races, that is, at a lower level than that of the species. The supremacy of the white 'race' is thus rejected: 'The class of the whites is not distinguished from that of the blacks as a special kind within the human species, and there are no different kinds of human beings' (DCR, 8: 99-IOO).

Once a skin colour has developed, it remains constant for each race, and the white race has adapted to climatic conditions just as much as all others. Kant thus gives up on his ordering of races, as well as on the question of the 'original race': 'It is therefore impossible to guess the shape of the first human phylum (as far as the constitution of the skin is concerned); even the character of the whites is only the development of 
one of the original predispositions that together with the others were to be found in that phylum' (DCR, 8: I06). Given that the white race, too, has developed its characteristics from the original 'germ', it cannot have been the original race. In this essay, Kant presents a much thinner concept of race: he carefully leaves out, and at times even corrects, the prejudices of the earlier text while retaining his case for the unity of the species. This is an essay on race free of racial hierarchies - in other words, a case of non-racist race theory. This theory is the clearest expression of a new definition of the concept of race, inspired by Kant's doubts concerning the veracity of the prejudices against the 'barbarians'.

\section{Race and History: Kant's Debate with Herder and Georg Forster}

His new definition of the concept of race leads Kant straight into a debate with Georg Forster, ${ }^{19}$ provoked in part by Kant's I 785 review of Johann Gottfried Herder's Outline of a Philosophical History of Humanity, the second part of which had been published in the same year. As Herder's text was a response to Kant's 'Idea for a Universal History' (I 784), Kant responded with his 'Conjectural Beginning of Human History' ( I 785) to the first volume of Herder's Philosophical History, among others. Herder had opened that volume with descriptions of different peoples, reasoning that 'these varieties are already noticed in elementary treatises on natural history' (Herder I 800: I32). These 'elementary treatises', however, rely exactly on the kind of descriptions that Herder does not consider particularly trustworthy - with the exception of the newest reports from Cook's voyage, provided by Georg Forster and his father Reinhold Forster.

Kant's review takes up Herder's 'wish for a collection of new portrayals of nations' (RH, 8: 58) and acknowledges the problem of 'the immeasurable multiplicity of ethnographic descriptions or travel narratives and all their conjectural records belonging to human nature, especially those in which they contradict one another' (6I-2). Analysing them yields arbitrary results:

One can prove, if one wants to, that Americans, Tibetans, and other genuine Mongolian peoples have no beard, but also, if it suits you better, that all of them are by nature bearded and only pluck them out; that Americans and Negroes are each a race, sunk beneath the remaining members of the human species in their mental presuppositions, but on the other side by just as apparent records that as regards their natural predispositions, they are to be estimated equal to every other inhabitant of the world; so it remains to the choice of the philosopher whether he wants to 
assume differences of nature or wants to judge everything in accordance the principle tout comme chez nous. (RH, 8: 62)

What those reports cannot provide is the sound foundation for a system (RH, 8: 62). Kant responds by suggesting that one speak of different races, distinguished by skin colour. In contrast, Herder prefers to speak of cultural differences in response to climatic conditions.

Kant and Herder are soon joined by Georg Forster in their debate over the dubious veracity of observations of nature. Forster understands Kant's statements as an attack not only on his vocation as traveller and author but also on his particular style of writing in a 'philosophical' rather than merely sober-factual manner. To him, his travel reports amounted to a form of 'literary sympathy', derived from personal experiences with foreign peoples (cf. Peitsch 2006: I60). Forster distinguishes his travel reports from an older variant dating back to the colonial travels of Spanish explorers and considers his innovation as an elevation of scientific standards (Forster 2000: 9). On the one hand, then, these reports represent a new type of travel report. On the other, it is easy to imagine how Kant may have felt provoked by Herder's claim to write 'philosophical history' while rejecting the idea of a 'system'. Kant had already reprimanded Herder for his 'poetical spirit', taking 'allegories for truth', and for 'the fabric of bold metaphors, poetic images, mythological allusions' (RH, 8: 60). Kant's examples are likely to have offended Forster as well, who considered himself aligned with Herder both in friendship and intellectual orientation.

Kant's 'Determination of the Concept of a Human Race' of November I 785 and his 'Conjectural Beginning of Human History' (also published in the Berlinischen Monatsschrift in January I786) provoked Georg Forster to write a scathing reply titled 'Something More on the Human Races'. Georg Forster had sailed around the globe with James Cook and was considered one of Germany's most important world travellers, along with his father and Alexander von Humboldt. The young Forster combined his annoyance over the criticism of travellers with a defence of the Linnéan method as a proven tool of making precise observations (Forster I 969: 76). Forster's work is based on the theory of the scala naturae, the 'natural chain' or 'great chain of being', according to which everything proceeds gradually. The gap between man and ape thus had to be filled - by an ape-like man. Forster may reject the concept of race, but he does so only because he follows an alternative system of 
classification which likewise requires differences in order to then identify classes and species based on similarities.

The core of the argument over skin colours is disagreement on the 'black race'. Forster takes the side of the polygenists when he accepts the assumption that there were multiple original human species (Forster I969: 97). He takes up the concern that this assumption of different species of blacks and whites may support the European feeling of superiority by asking, in turn, whether 'the idea, that black people are our brothers, had anywhere, at any time, moved the slave driver to lower his whip' (99, translation mine). The proof of a common origin was powerless against the practice of slavery. The lack of sympathy was responsible for the despotic rule of white subjects and for slavery (ibid.). In contrast, Forster thinks that the idea of a second human species may be a 'forceful means to develop thoughts and sentiments suitable to a reasonable earthly creature (Ioo, translation mine). ${ }^{20}$ Forster condemns contemporary colonialism and demands reforms - but in a way which would put the 'white' in the place of a 'father' of the 'black race' to 'ennoble' it (ibid., translation mine). ${ }^{2 \mathrm{I}}$

Once again, the critique of colonialism appears as the reform of colonialism. Unlike today's readers, Forster does not question Kant's criticism of colonialism and the treatment of black people, but he does not believe that Kant's theoretical reasoning - based on the monogenetic thesis of a common origin of humankind - can play a useful role in explaining the necessity of reform. In contrast, Forster hopes for an educational effect of the assumption of the different human species - an expectation Kant finds (presumably in accordance with today's readers) implausible.

Kant responds to Forster's harsh criticism ${ }^{22}$ with 'On the Use of Teleological Principles in Philosophy' (I788), an extensive and conciliatory response that is mild in tone and dedicated to finding common ground, but which nonetheless strictly maintains his position. Teleological principles determine the 'natural end' or 'natural purpose' (Naturzweck) a priori through purely practical reason. They could 'establish a principle in advance which is supposed to guide the investigator of nature even in searching and observing', while its absence limited the investigation to 'mere empirical groping' (UTP, 8: I6I). Kant again stressed the importance of this proposition for the discussion of the origin of the 'black race': to follow Linné in looking for similarities carries the risk of overlooking the proof for the common origin of humankind. That risk showed clearly 'that one must be guided by a determinate principle 
merely in order to observe, i.e., to pay attention to that which could indicate the phyletic origin, not just the resemblance of characters' (I64).

Kant thus retains his distinction between the observation of nature and natural history. The latter

would only consist of tracing back, as far as the analogy permits, the connection between certain present-day conditions of the things in nature and their causes in earlier times according to laws of efficient causality, which we do not make up but derive from the powers of nature as it presents itself to us. (UTP, 8: I62)

This is why Kant continues to use the term 'race', understood as a 'concept' that cannot be rejected simply because it was not part of Linné's system; to do so would be to deny the thing itself (UTP, 8: I 63). Rather, 'race' was a concept from natural history, where it served as one of the categories alongside phyla and 'human sorts'. At issue, then, was 'an idea of the way in which the greatest degree of manifoldness in the generation can be united by reason with the greatest unity of phyletic origin' ( 164 ). Kant emphasizes the distinction between differences between 'races' and differences between species (I65). The object of investigation may be differences, but those must not be exaggerated through predetermined classifications, in order to maintain the 'common origin'.

At its moment of origin, all members of the human species carried within themselves the germs of all possible characteristics and subsequently developed them according to their climatic surroundings. A second phase of adaptation could be described as inertia based on this development: once 'races' had adapted to a certain climate, they tended to stay there, which explained the lack of northbound migration by Indian and 'black' peoples. Where individual peoples had defied that trend, the results were not encouraging. Kant attempts to illustrate this by the example of the 'gypsies' who 'have never been able to bring about in their progeny ... a sort that would be fit for farmers or manual labourers' (UTP, 8: I74). In a footnote, he takes this example further by way of referencing a report on freed 'Negro slaves' who never 'engaged in a business which one could properly call labor' and instead chose casual employment and ultimately became 'hawkers' (I74n.) Kant infers from this that there existed an independent 'drive to activity' he called industry (Emsigkeit) and which is 
especially interwoven with certain natural predispositions; and that Indians as well as Negroes do not bring any more of this impetus into other climates and pass it on to their offspring than was needed for their preservation in their old motherland and had been received from nature; and that this inner predisposition extinguishes just as little as the externally visible one. The far lesser needs in those countries and the little effort it takes to procure only them demand no greater predispositions to activity. (UTP, 8: I74n.)

This passage from a footnote in 'On the Use of Teleological Principles in Philosophy' and its citation of the writings of an anti-abolitionist author is commonly read as a fusion of 'racist' and moralistic characterizations. According to this interpretation, Kant here confirms his belief in the 'natural inferiority of non-whites' (Kleingeld 2012: I06). ${ }^{23}$

A different aspect of Kant's interest emerges when we extend the scope to include the discussion of the development out of the (pre-state) state of nature. Kant, who has described the state of nature as a state of misery, now accepts the idea of a simple life in hot climates which required 'little effort' and interprets the lesser 'drive to activity' as adaptation to the abundance found in hotter regions. Furthermore, the same adaptation now became visible among Americans who migrated from the South northwards across the headland to America and back toward the South without the opportunity to completely adapt.

That their natural disposition did not achieve a perfect suitability for any climate, can be seen from the circumstance that hardly another reason can be given for why this race, which is too weak for hard labor, too indifferent for industry and incapable for any culture - although there is enough of it as example and encouragement nearby - ranks still far below even the Negro, who stands on the lowest of all the other steps that we have named as differences of the races. (TPP, 8: I75-6)

Kant clearly articulates strongly negative evaluations here. But the 'racial difference' he is referencing is just 'predisposition to activity'. In other words, Kant takes the supposedly weaker drive to activity among Americans and Africans to be a racial difference. He does not describe a case of cultural or moral failure but a logical and naturally caused case of adaptation to given conditions - an adaptation that loses its validity in different contexts and then appears as indolence. Kant avoids the 
evaluative word 'laziness' that he had used previously. He supports his argument by referring to the anti-abolitionist James Tobin who had reported that freed black slaves never chose farming as their vocation. The emphasis here should not be read as lying on work as such, but on the description of agriculture as a 'capacity' required to prepare the advance of a society into state-ness. Kant wants to know whether freed slaves take up farming, and if they do not, then their choice proves their original adaption to climatic conditions in the South which rendered agriculture unnecessary and thereby prevented differentiation to the degree that it was seen in Europe. The issue of agriculture was crucial in the Scottish Enlightenment's discussion of humanity's stages as hunters and gatherers, herdsmen and farmers, as well as in Montesquieu's work (cf. Meek 20IO), and its treatment by Kant is the crucial point of the cited passage - and not his position on the question of slavery. To Kant, Americans are 'idle' because that is part of their adaptation - there is no point in condemning it, as it can explained as part of the natural history of humans.

The level of explanation is that of 'race' - a biological level based on the assumption of prehistorical imprint. The identification of idleness confirms Rousseau's dictum of the 'savage' who, when his hunger is satisfied, lives in peace with all of nature and is everybody's friend. To read Kant's statement negatively, as a pejorative description in the sense of 'laziness' means to remain stuck in the categories of a 'work society' which, according to Rousseau is the direct opposite to this way of life. ${ }^{24}$ For Kant, idleness (a description) is not laziness (a moral evaluation) but a form of natural adaptation which follows necessities. Idleness is a natural trait. It cannot be condemned, but it can in Kant's view be observed and noted. His search for evidence for this thesis led him to Tobin, but his acceptance of Tobin's observation does not translate into an affirmation of his position on slavery.

Kant does speak of 'steps' and 'the lowest of all steps', and of being 'incapable of any culture'. The standard used here is, of course, European culture, but also Japan, Persia or China. These 'cultures' are marked by social institutions and habits similar to Europe's, that is, those that primarily stand in for state-ness.

Kant intended to recognize the unity of the human species as biological creatures and needed to explain its differences in the process. To do so, he developed the concept of race, determined by the hereditary characteristic of skin colour. He works with 'observable' differences: industry resulted 
in a higher position in the global hierarchy and industry seems to be attached to 'races' determined by skin colour. Kant's explanation of these differences does not mean affirmation: to him, the lack of highly developed public order, organization and technology suggests the supposed lack of an urge to activity, which in turn is understood as a consequence of the different processes of adaptation to climatic conditions undergone by the different 'races'.

\section{Conclusion}

Kant's concept of race undergoes a transformation. It begins with the climate-theoretic categorization of extremes and a hierarchy of the origins of different races, moves on to a non-hierarchical concept of race, and ultimately arrives at a notion that identifies activity teleologically as a characteristic and uses it to confirm power relations and differences in the political world. As problematic as the third and final version may be, it does not amount to an affirmation of those relations.

The final stage serves as the new point of departure for Kant's thought as he realizes the globalization of the violent potential of European, 'barbarian', states. Accordingly - and thematically fitting with his I 775 writings on race, albeit without using the term 'race' - Kant writes in the Physical Geography: 'The inhabitant of the temperate zone, especially in its central part, is more beautiful in body, harder working, more witty, more moderate in his passions, and more sensible than any other kind of people in the world. Consequently, these people have always taught the rest [of the world] and vanquished them by the use of weapons' $(P G, 9: 3 I 7)$.

The point of this article is not to deny that Kant expressed prejudices against non-Europeans. He did, without a doubt, repeatedly and more or less uncritically. The point is also not to argue for any concept of 'race'. The point has been to show that Kant's use of the concept of 'race' is consistent with his anti-colonial legal theory. Kant underwent a gradual change of opinion concerning non-European peoples that can also be identified in his essays on race and is consistent with his late anticolonialism. One problem that could not be covered up here is his contribution to theorizing a type of superiority based on the image of the state of nature in the theory of the state: Kant follows Hobbes in equating it with the 'lawless condition' of the 'savage' and thus comes to be convinced of the inferiority of non-state forms of social life vis-à-vis state-building ones. 
Traditionally, we have taken Kant's change of heart to consist in having given up his racist views (views on racial hierarchy) and embracing egalitarian global law and anti-colonialism in his late writings. This article has shown that Kant's change of heart lay in moving from uncritical repetition of European prejudices to a non-racist theory of race in $\mathrm{I} 785$ that is determined to reject the assumptions of different human species. His anticolonialism and the development of his race theory can be understood as consistently motivated and not distinguished by racist motives for the race theory and anti-colonial intentions for the legal theory. In his engagement with travel reports and the prejudices against non-European peoples that have their foundation in the barbarism discourse, Kant increasingly enlightened his own judgements to the point where he no longer trusted those reports at all and instead relied on a biological determination of 'races'.

The racial hierarchy contained in his concept of race corresponds to the colonial reality of a world currently reordered through European expansion without affirming it. Kant was aware that the reason for the success of European expansion was rooted in state-based organization, a positive work ethic and technological advantage. He does not condemn this development in his writings on race but investigates the reason for those differences. He finds them in the Europeans' industry and the 'idleness' (Trägheit) of Africans, understood in both cases as a race's adaptation to climatic condition that can no longer be changed.

Kant does not seek to ground moral judgements in his writings on race. Conversely, the moral evaluation of European expansion can be found in Perpetual Peace and The Metaphysics of Morals. The anti-colonial thrust of these writings is not inconsistent with the writings on race but provides a loose unity. But if such a consistency between Kant's writings on rights and those on race is possible, it also changes our interpretation of his position on colonialism. Kant did not start condemning colonialism only with his essay on peace but had criticized its conceptual foundations much earlier. Anti-colonialism is a feature of his writings on race as well as his legal theory. ${ }^{25}$

\section{Notes}

I See Kleingeld 2007: 575, Bernasconi 20II: 295 and 293, Kleingeld 20I4: 65, Mills 2005: I73, McCarthy 2009: 26.

2 Similarly, Muthu (2003: I 83) argues that the term race 'disappears' from his published writings after 1790 , suggesting a change of mind on the issue.

3 See also Flikschuh and Ypi 20I4, Williams 20I4, Muthu 2003: I72-209, Kleingeld 20I2, Eberl and Niesen $201 \mathrm{I}$. 
4 Pauline Kleingeld holds that Kant maintained his old opinions until I792: 'By the middle of the I790s, however, he has radically changed his mind on the subject of race. He starts to criticize slavery, the slave trade, and colonialism, explicitly attributing full juridical status to non-whites under the new category of "cosmopolitan right", changing his description of the characteristics of the races, and regarding continued global migration and trade as part of the plan of nature' (Kleingeld 2OI 2: III).

5 See Borst I988: I9-3I, Nippel I990, Detel 1995, Münkler 2008, Wallerstein 2006, Osterhammel 2005, Boletsi 20I3, Rawson 200I, Todorov I985, Pagden I 982.

6 McCarthy has written about the dichotomy of 'barbaric'-'civilized', but understands it as a pattern that essentially belongs to the nineteenth century (cf. 2009: 27).

7 Reinhard Koselleck (2006) provides a vivid description of the asymmetrical structure of the concept of the 'barbarian'. At the same time, however, his Schmittian approach suggests that all subsequent terms of discrimination, including the Nazi era concept of the 'subhuman' (Untermensch), should be understood as mere successors of the 'barbarism' discourse. As a consequence, the concept of 'subhuman' has its specific connotation (and intention) of genocidal extermination. Following Koselleck, Annette Barkhaus (2006) reads Kant as 'translating' the barbarism discourse into a race discourse.

8 This distinction between the human history as an animal and the idea of its rights is also stressed in today's accounts of the history of humankind, see for example Harari (2015: I09).

9 Whenever possible and unless otherwise noted, I use the translations provided by the Cambridge Edition of the Works of Immanuel Kant, with the standard Akademie pagination (as carried in the margins of that edition), and the following abbreviations. $M M=$ Metaphysics of Morals, PP = Perpetual Peace (in Kant 1996); CJ = Critique of the Power of Judgement (Kant 2000); DCR = 'Determination of the Concept of a Human Race', $\mathrm{IUH}=$ 'Idea for a Universal history with a Cosmopolitan Intent', $O B S=$ Observations on the Feeling of the Beautiful and Sublime, ODR = 'Of the Different Races of Human Beings', RH = Review of J. G. Herder's Ideas for the Philosophy of the History of Humanity. Parts $I$ and 2; UTP $=$ 'On the Use of Teleological Principles in Philosophy' (in Kant 2007); APG ='Plan and announcement of a series of lectures on physical geography with an appendix containing a brief consideration of the question: Whether the West winds in our regions are moist because they travel over a great sea', $P G$ = Physical Geography (in Kant 20I 2); DR = Drafts for Perpetual Peace (in Kant 20I 6); and RA = Reflections on Anthropology.

Io On this topic, see the majority of the contributions in Elden and Mendieta 20II.

II 'I have used all sources, sought out all information, and, in addition to what the works of Varenius, Buffon, and Lulof contain in the way of the general fundaments of physical geography, I have gone through the most thorough descriptions of individual countries by capable travellers, the Allgemeine Historie der Reisen, the Göttingische Sammlung neuer und merkwürdiger Reisen, the Hamburg and the Leipzig Magazines, the Proceedings of the Acedémie des Sciences in Paris and the Stockholm Academy and so forth, and I have constructed a system out of everything relevant to my purpose.' (APG, 2: 4).

I2 'Homo americanus: red, choleric, erect; hair black, straight, thick; nostrils wide; face harsh; beard scanty, obstinate, content, free; paints himself with fine red lines; regulated by customs

Homo europaeus: white, sanguine, muscular; hair yellow, long; eyes blue; gentle acute, inventive; covered with close vestments; governed by laws

Homo asiaticus: pale yellow, melancholy, inflexible; hair black; eyes dark; serious, proud, avaricious; covered with loose garments; governed by opinions 
Homo afer: black, phlegmatic, relaxed; hair black, tangled; skin silky, nose flat, lips tumid; crafty, indolent, negligent; anoints himself with grease; governed by caprice.' (In Jablonski 20I 2: I28)

13 Arthur Ripstein also stresses Kant's condemnation of war as 'barbaric'. He takes 'barbaric' to be 'a technical term for Kant' (2016: I79) and draws on Kant's use of it in his system of states in the Anthropology (7:33I). But Ripstein misses Kant's criticism of the older use of the term, and its interpretation as a 'technical term' describes his own position more accurately than Kant's. See also Bertram 20Io. Ripstein's interpretation of the 'violation of the postulate of public right' as the 'distinctive feature of barbarism' (2009: 339-40) conflates barbarism in the end with the 'state of nature'. This is clearly in Kant's sense and has inspired social theory and criticism through the last two hundred years, but still it is a highly problematic use of a conceptual dichotomy that leads directly to the distinction between democracies and the 'unjust enemy' as incarnation of the 'barbarian state'; see e.g. Bernstein 20I4.

I4 This, again, is in line with Harari's account of the history of humankind, cf. 201 5: I09.

I5 Statements pointing in the opposite direction - certainly written much later - can be found, for instance, in the Physical Geography: 'Even in the case of the captain who was captured as a young Negro boy and who became famous in Holland for his learning, it is highly probable that it was his longing for his homeland that made him leave Europe.' (PG, 9: 248).

I6 Similarly, Kant writes in his Physical Geography: 'The friendship of these savages is taken to extraordinary lengths.' In the same passage, he also notes 'the great inclination of these people to independence' ( $P G, 9: 433)$.

17 Voltaire published two essays on race, the first similar to Hume's essay, titled Essai sur les mours et l'esprit des nations (Essay on the Manners and Spirit of Nations, first edition I756) and La Philosophie de l'histoire (The Philosophy of History, first edition I765) with the first chapter 'Of the Different Races of Man'. Already in 1734 Voltaire displayed negrophobic ressentiments in his Traité de Métaphysique.

I8 Despite the resemblance to Linné's evaluations, Koller argues that Kant's are not moral judgements of different 'races' (20II: 27).

I9 On this debate, see Godel and Stiening 20 I2.

20 Forster's choice of words strongly suggests a polygenistic approach, against Pauline Kleingeld's argument that explicitly rejects this reading, particularly of Forster's late writing (20I 2: I07). See on Forster's polygenism van Horn (2004).

2I In Forster's words directed at the 'white': 'Du solltest Vaterstelle an ihm vertreten, und indem du den heiligen Funken der Vernunft in ihm entwickeltest, das Werk der Veredlung vollbringen, was sonst nur ein Halbgott, wie du oft glaubtest, auf Erden vermogte. Durch dich konnte, sollte er werden, was du bist, oder seyn kannst, ein Wesen, das im Gebrauch aller in ihm gelegten Kräfte glücklich ist' (Forster I969: 100).

22 Forster ultimately regretted the acerbity of his criticism of Kant, according to a letter sent to Johann Benjamin Jachmann in the aftermath of the debate, in the fall of $\mathrm{I} 790$ (Lepenies I988: I45).

23 Bernasconi (2002: I48) has traced Kant's reference to Tobin to Sprengel's Beiträge zur Völker und Landerkunde, vol. 5 (I 786 ) and joins Kleingeld in interpreting it as a sign of Kant's affirmation of Tobin's anti-abolitionist position. (See the discussion that follows in the main text.)

24 Kant's use of the two terms is not always consistent. In the Physical Geography he writes: 'The inhabitants of the hottest zone are exceptionally indolent. In some cases, this laziness is tempered to an extent by the government and by force ... their indolence caused them to choose to go hungry in the forests rather than work' (9: $3 \mathrm{I} 6$ ). 
25 This research received funding from the Alexander von Humboldt-Foundation through a Feodor-Lynen Fellowship that supported my research stay at Indiana University, Bloomington, in 2018. There, I greatly benefited from very helpful discussions with my academic host, William E. Scheuerman, as well as with Allen Wood, Russ Hanson and Volker Schmitz. Many thanks also go to the participants of the panel on 'Kantian Political Theory and Global Change' at the ECPR General Conference in Hamburg, 20I 8, and to the two anonymous reviewers. I am also grateful for a very helpful comment by Inés Valdez.

\section{References}

Barkhaus, Annette (2006) 'Rasse: Zur Genese eines spezifisch neuzeitlichen Ordnungsbegriffs'. In Hansjörg Bay and Kau Merten (eds), Die Ordnung der Kulturen: Zur Konstruktion ethnischer, nationaler und zivilisatorischer Differenzen I750-I 850 (Würzburg: Königshausen und Neumann), pp. 33-52.

Bernasconi, Robert (200I) 'Who Invented the Concept of Race? Kant's Role in the Enlightenment Construction of Race'. In Robert Bernasconi (ed.), Race (Oxford: Blackwell Publishers), pp. I I-36.

- (2002) 'Kant as an Unfamiliar Source of Racism'. In Julie K. Ward and Tommy L. Lott (eds), Philosophers on Race: Critical Essays (Oxford: Blackwell Publishers), pp. I45-66.

_ (20II) 'Kant's Third Thoughts on Race'. In Stuart Elden and Eduardo Mendieta (eds), Reading Kant's Geography (Albany, NY: SUNY Press), pp. 29I-3I 8.

Bernstein, Alyssa R. (2014) 'The Rights of States, the Rule of Law, and Coercion: Reflections on Pauline Kleingeld's Kant and Cosmopolitanism'. Kantian Review, I9/2, 233-49.

Bertram, Chris (2010) Ripstein, Kant, and Barbarism. http://crookedtimber.org/2010/09/2 I/ ripstein-kant-and-barbarism/ (accessed 25 June 20I8).

Boletsi, Maria (2013) Barbarism and its Discontents. Stanford, CA: Stanford University Press.

Borst, Arno (I988) 'Barbaren. Geschichte eines europäischen Schlagwortes'. In Arno Borst, Barbaren, Ketzer und Artisten. Welten des Mittelalters (Munich: Piper), pp. I9-3 I.

Detel, Wolfgang (1995) 'Griechen und Barbaren: $\mathrm{Zu}$ den Anfängen des abendländischen Rassismus'. Deutsche Zeitschrift für Philosophie, 43/6, Iог19-43.

Eberl, Oliver (2018) 'Der Staat und die Fremden: "Barbarei”, "Edle Wilde" und die Kritik der Gesellschaft mit Montaigne und Rousseau'. In Norbert Campagna and Franziska Martinsen (eds), Staatsverständnisse in Frankreich (Baden-Baden: Nomos), pp. 223-42.

— and Niesen, Peter (20II) Immanuel Kant. Zum Ewigen Frieden/Auszüge aus der Rechtslehre: Kommentar. Berlin: Suhrkamp.

Elden, Stuart and Mendieta, Eduardo (eds) (20I I) Reading Kant's Geography. Albany, NY: SUNY Press.

Ette, Ottmar (2014) Anton Wilhelm Amo. Philosophieren ohne festen Wohnsitz: Eine Philosophie der Aufklärung zwischen Europa und Afrika. Berlin: Kulturverlag Kadmos.

Eze, Emmanuel Chukwudi (I997) 'The Color of Reason: The Idea of "Race" in Kant's Anthropology'. In Emmanuel Eze (ed.), Postcolonial African Philosophy. A Critical Reader (Oxford: Blackwell Publishers), pp. 103-33.

Fink-Eitel, Hinrich (1984) Die Philosophie und die Wilden: Über die Bedeutung des Fremden für die europäische Geistesgeschichte. Munich: Wilhelm Fink.

Flikschuh, Katrin and Ypi, Lea (eds) (2014) Kant and Colonialism: Historical and Critical Perspectives. Oxford: Oxford University Press.

Forster, Georg (I969) 'Noch etwas über die Menschenraßen'. In Georg Forster, Werke in vier Bänden. Ed. Gerhard Steiner, vol. 2 (Frankfurt am Main: Insel), pp. 7 I-IOI. 
(2000) A Voyage Round the World, vol. I. Ed. Nicholas Thomas and Oliver Berghof. Honolulu: University of Hawai'i Press.

Garrett, Aaron (2000) 'Hume's Revised Racism Revisited'. Hume Studies, 26/I, I7 I-8.

Girtanner, Christoph (I796) Ueber das Kantische Prinzip für die Naturgeschichte. Göttingen: Vandenhoek \& Ruprecht.

Godel, Rainer and Stiening, Gideon (eds) (20I2) Kopffechterreien - Missverständnisse Widersprüche? Methodische und methodologische Perspektiven auf die Kant-ForsterKontroverse. Munich: Wilhelm Fink Verlag.

Harari, Yuval Noah (20I 5 ) Sapiens: A Brief History of Humankind. New York: Harper Collins. Herder, Johann Gottfried ( 1800 ) Outlines of a Philosophy of the History of Man. Trans. T. Churchill. Great Turnstile, Lincoln's-Inn Fields: Luke Hansard.

Hume, David (n.d.) Essays, Literary, Moral, and Political. London: Ward, Lock \& Co.

Hund, Wulf D. (I999) 'Im Schatten des Glücks: Philosophischer Rassismus bei Aristoteles und Kant'. In Wulf Hund, Rassismus: Die soziale Konstruktion natürlicher Ungleichheit (Münster: Westfälisches Dampfboot), pp. I Io-26.

- (20I I) 'It Must Come from Europe: The Racism of Immanuel Kant'. In Wulf D. Hund, Christian Koller and Moshe Zimmermann (eds), Racism Made in Germany (Vienna and Berlin: Lit Verlag), pp. 69-98.

Jablonski, Nina G. (20I2) Living Color: The Biological and Social Meaning of Skin Color. Berkeley, CA: University of California Press.

Kant, Immanuel (1996) Practical Philosophy. Trans. and ed. Mary J. Gregor. Cambridge: Cambridge University Press.

- (2000) Critique of the Power of Judgment. Ed. Paul Guyer, trans. Paul Guyer and Eric Matthews. Cambridge: Cambridge University Press.

(2007) Anthropology, History, and Education. Ed. Robert B. Louden and Günter Zöller. Cambridge: Cambridge University Press.

— (20I2) Natural Science. Ed. Eric Watkins. Cambridge: Cambridge University Press.

- (2016) Lectures and Drafts on Political Philosophy. Ed. Fred Rauscher. Cambridge: Cambridge University Press.

Kleingeld, Pauline (2007) 'Kant's Second Thoughts on Race'. Philosophical Quarterly, 229, 573-92.

- (2012) Kant and Cosmopolitanism: The Philosophical Idea of World Citizenship. Cambridge: Cambridge University Press.

- (2014) 'Kant's Second Thoughts on Colonialism'. In Katrin Flikschuh and Lea Ypi (eds), Kant and Colonialism: Historical and Critical Perspectives (Oxford: Oxford University Press), pp. 43-67.

Koller, Christian (2OII) 'Racism Made in Germany. Without "Sonderweg" to a "Rupture in Civilization”'. In Wolf D. Hund, Christian Koller and Moshe Zimmermann (eds), Racism Made in Germany (Vienna and Berlin: LIT Verlag), pp. 9-40.

Koselleck, Reinhart (2006) 'Zur historisch-politischen Semantik asymmetrischer Gegenbegriffe'. In Reinhart Koselleck, Vergangene Zukunft: Zur Semantik geschichtlicher Zeiten (Frankfurt am Main: Suhrkamp), pp. 2 I I-59.

Lahontan, Louis Armand de (1973) Dialogues avec un sauvage. Paris: Éditions Sociales. (1982) Neueste Reisen nach dem mitternächtlichen Amerika. Berlin: Freitag Verlag.

Lepenies, Wolf (I988) 'Georg Forster als Anthropologe und Schriftsteller'. In Wolf Lepenies, Autoren und Wissenschaftler im I8. Jahrhundert (Munich and Vienna: Carl Hanser), pp. I 2 I -54 . 
McCarthy, Thomas A. (2009) Race, Empire, and the Idea of Human Development. Cambridge: Cambridge University Press.

Meek, Ronald L. (2010) Social Sciences and the Ignoble Savage. Cambridge: Cambridge University Press.

Mills, Charles W. (2005) 'Kant's Untermenschen'. In Andrew Valls (ed.), Race and Racism in Modern Philosophy (Ithaca, NY: Cornell University Press), pp. I67-93.

Münkler, Herfried (2008) 'Barbaren und Dämonen: Die Konstruktion des Fremden in Imperialen Ordnungen'. In Jörg Baberowski, Hartmut Kaelble and Jürgen Schriewer (eds), Selbstbilder und Fremdbilder: Repräsentationen sozialer Ordnung im Wandel (Frankfurt/New York: Campus), pp. I 53-89.

Muthu, Sankar (2003) Enlightenment Against Europe. Princeton: Princeton University Press.

Nippel, Wilfried (I990) Griechen, Barbaren und 'Wilde': Alte Geschichte und Sozialanthropologie. Frankfurt am Main: Fischer.

Osterhammel, Jürgen (2005) 'The Great Work of Uplifting Mankind'. In Jürgen Osterhammel and Boris Barth (eds), Zivilisierungsmissionen: Imperialie Weltverbesserung seit dem I8. Jahrhundert (Konstanz: Universitätsverlag Konstanz), pp. 363-425.

Pagden, Anthony (1982) The Fall of Natural Man: The American Indian and the Origins of Comparative Ethnology. Cambridge: Cambridge University Press.

— (1990) 'Dispossessing the Barbarian: The Language of Spanish Thomism and the Debate over the Property Rights of the American Indians'. In Anthony Pagden (ed.), The Languages of Political Theory in Early Modern Europe (Cambridge: Cambridge University Press), pp. 79-98.

Peitsch, Helmut (2006) "“Noch war die halbe Oberfläche der Erdkugel von tiefer Nacht bedeckt." Georg Forster über die Bedeutung der Reisen der europäischen "Seemächte" für das deutsche "Publikum"'. In Hans-Jürgen Lüsebrink (ed.), Das Europa der Aufklärung (Göttingen: Wallstein), pp. I 57-74.

Rawson, Claude (200I) God, Gulliver, and Genocide: Barbarism and European Imagination, I492-I945. Oxford: Oxford University Press.

Ripstein, Arthur (2009) Force and Freedom: Kant's Legal and Political Philosophy. Cambridge, MA: Harvard University Press.

— (2016) 'Just War, Regular War, and Perpetual Peace'. Kant-Studien, I07, I79-95.

Sandford, Stella (20I 8) 'Kant, Race, and Natural History'. Philosophy and Social Criticism, 44, $950-77$.

Stark, Werner (20II) 'Kant's Lectures on "Physical Geography": A Brief Outline of its Origins, Transmission, and Development: I754-I805'. In Stuart Elden and Eduardo Mendieta (eds), Reading Kant's Geography (Albany, NY: SUNY Press), pp. 69-85.

Todorov, Tzvetan (1985) Die Eroberung Amerikas: Das Problem des Anderen. Frankfurt am Main: Suhrkamp.

Valdez, Inés (20I7) 'It's Not about Race: Good Wars, Bad Wars, and the Origins of Kant's Anti-Colonialism'. American Political Science Review, II I/4, 8I9-34.

Van Horn, Tanja (2004) Dem Leibe abgelesen: Georg Forster im Kontext der physischen Anthropologie des I 8. Jahrhunderts. Tübingen: Max Niemeyer Verlag.

Wallerstein, Immanuel (2006) European Universalism: The Rhetoric of Power. New York: New Press.

Williams, Howard (2014) 'Colonialism in Kant's Political Philosophy'. Diametros, 39, I 54-8I. 